\title{
Reproductive biology of the cockfish, Callorhinchus callorynchus (Chondrichthyes: Callorhinchidae), in coastal waters of the northern Argentinean Sea
}

\author{
Melisa A. Chierichetti ${ }^{1}$, Lorena B. Scenna ${ }^{1,2}$, Edgardo E. Di Giácomo ${ }^{3}$, \\ Paola M. Ondarza ${ }^{2,4}$, Daniel E. Figueroa ${ }^{1}$ and Karina S. B. Miglioranza ${ }^{2,4}$
}

The cockfish, Callorhinchus callorynchus, is a widely distributed holocephalan in the south-western Atlantic and an important resource for Argentinean fisheries. The reproductive characteristics of this species were studied in northern Argentinean coastal waters, where specimens arrive seasonally (winter-spring). Sexual dimorphism in maximum precaudal length (PCL) and total body mass (TM) was found, being females (PCL=630 mm; TM=3330 g; n=167) larger and heavier than males $(\mathrm{PCL}=482 \mathrm{~mm}$; TM=1630 $\mathrm{g} ; \mathrm{n}=19)$. Maturity size for females was $466.22 \mathrm{~mm}$ PCL, representing $74 \% \mathrm{PCL}$ of the largest female sampled. The mean number of ovarian follicles was $8.37( \pm 4.84)$. The highest values of ovarian follicles diameter, gonadosomatic and oviducalsomatic indices were found in spring. A high proportion of mature females (44\%) had atretic ovarian follicles, suggesting that they were in the resting stage of their reproductive cycle. The low number of mature males recorded and the absence of mature females with spermatophore masses or egg cases indicate that the study area would not be a reproductive zone. The seasonal presence of $C$. callorynchus in this region could be related to trophic movements. These results, obtained in an area with high fishing pressure on chondrichthyans, will be useful for implementing conservation and management measures.

Keywords: Holocephalans, Maturity, Ovarian fecundity, Seasonality, South-western Atlantic.

El pez gallo, Callorhinchus callorynchus, es un holocéfalo con amplia distribución en el Atlántico Sudoccidental y un recurso importante para las pesquerías en Argentina. Las características reproductivas de esta especie fueron estudiadas en aguas costeras al norte del Mar Argentino, adonde se acercan estacionalmente (invierno-primavera). Se observó dimorfismo sexual en los valores máximos de longitud precaudal (LPC) y masa corporal total (MT), siendo las hembras ( $\mathrm{LPC}=630 \mathrm{~mm}$; MT=3330 g; $\mathrm{n}=167$ ) más grandes y pesadas que los machos ( $\mathrm{LPC}=482 \mathrm{~mm} ; \mathrm{MT}=1630 \mathrm{~g} ; \mathrm{n}=19)$. La talla de maduración para las hembras fue de 466,22 $\mathrm{mm}$ LPC, representando el 74\% de la LPC máxima observada. El número promedio de folículos ováricos fue 8,37 $( \pm 4,84)$. Los valores más altos del diámetro de los folículos ováricos, índice de la glándula oviductal e índice gonadosomático fueron hallados durante primavera. Una gran proporción de hembras maduras (44\%) presentaron folículos ováricos atrésicos, sugiriendo que se encontraban en la etapa de reposo de su ciclo reproductivo. El bajo número de machos maduros registrados y la ausencia de hembras maduras con espermatóforos o cápsulas de huevos indican que las aguas costeras del norte de Argentina no serían una zona reproductiva. La presencia de $C$. callorynchus en el área de estudio podría estar relacionada con movimientos tróficos. Los resultados, obtenidos en un área con una gran presión pesquera sobre los condrictios, serán útiles para implementar adecuados planes de manejo y conservación de esta especie.

Palabras clave: Atlántico Sudoccidental, Estacionalidad, Fecundidad, Holocéfalos, Madurez sexual.

\footnotetext{
${ }^{1}$ Laboratorio de Ictiología, Instituto de Investigaciones Marinas y Costeras, Universidad Nacional de Mar del Plata, Funes 3350, B7602AYL, Mar del Plata, Argentina. (MAC) mcherichetti@mdp.edu.ar, (LBS) 1scenna@mdp.edu.ar (corresponding author), (DEF)dfiguer@mdp.edu.ar ${ }^{2}$ Consejo Nacional de Investigaciones Científicas y Técnicas, Avenida Rivadavia 1917, C1033AAJ, Ciudad Autónoma de Buenos Aires, Argentina. ${ }^{3}$ Grupo CONDROS, Laboratorio de Recursos Icticos, Instituto de Biología Marina y Pesquera "Almirante Storni", Universidad Nacional del Comahue, Güemes 1030, R8520CXV, San Antonio Oeste, Argentina. edgardodigiacomo@gmail.com ${ }^{4}$ Laboratorio de Ecotoxicología y Contaminación Ambiental, Instituto de Investigaciones Marinas y Costeras, Universidad Nacional de Mar del Plata, Funes 3350, B7602AYL, Mar del Plata, Argentina. (PMO) pmondar@mdp.edu.ar, (KSBM) kmiglior@mdp.edu.ar
} 


\section{Introduction}

Members of the family Callorhynchidae (Subclass Holocephali) are oviparous marine chondrichthyans, widely distributed in the Southern Hemisphere (Didier, 2004). This monogeneric family (genus Callorhinchus) includes three living species (Nelson, 2006). The cockfish Callorhinchus callorynchus (Linnaeus, 1758) occurs from $23^{\circ} \mathrm{S}$, in the south-western Atlantic, to $18^{\circ} \mathrm{S}$ in the Southeast Pacific (Cousseau, Perrotta, 2013). It is captured year-round as part of commercial bottom trawl fisheries in Argentina, Chile and Peru (Dagit et al., 2007; Consejo Federal Pesquero, 2009). Along the Argentinean Sea (south-western Atlantic Shelf between $35^{\circ} \mathrm{S}$ and $55^{\circ} \mathrm{S}$ ), this species is abundant from coastal waters to $200 \mathrm{~m}$ depth and an important resource for recreational and small artisanal fisheries (Consejo Federal Pesquero, 2009; Cedrola et al., 2011; Cousseau, Perrotta, 2013). Argentinean landings of C. callorynchus represent $97 \%$ of the total south-western Atlantic catches of this species (Bernasconi et al., 2015a). In addition, there has been an increase in Argentinean landings from 1992 to 2011, with the highest one recorded in 2009 (2782 tons) (Sánchez et al., 2012; Navarro et al., 2014; Bernasconi et al., 2015a).

Chondrichthyan populations have low biological productivity and therefore they require careful management and monitoring (Walker, 2005a). Knowledge on life history characteristics (e.g. reproductive cycles, size at maturity, fecundity, nursery grounds and habitat) is necessary to develop stock assessment models and ecological risk assessment in order to implement effective sustainable management practices (Bonfil, 2005). Despite its fishery importance and the wide distribution of C. callorynchus off southern South America, its life-history characteristics were studied only in northern Patagonian waters off Argentina $\left(41^{\circ}-42^{\circ} \mathrm{S} 64^{\circ}-65^{\circ} \mathrm{W}\right)$ (Di Giácomo, 1990, 1992; Di Giácomo, Perier, 1994, 1996; Di Giácomo et al., 1994; Bernasconi et al., 2015a, 2015b) and in coastal waters off Coquimbo ( $30^{\circ} 15^{\prime} \mathrm{S} 70^{\circ} 30^{\prime} \mathrm{W}$ ), Chile (Alarcón et al., 2011). In addition, the Argentinean port with the highest landings of chondrichthyans is located in the south-eastern Buenos Aires Province (Mar del Plata: $38^{\circ} 01^{\prime} \mathrm{S} 57^{\circ} 31^{\prime} \mathrm{W}$ ), where the abundance of $C$. callorynchus was reduced by nearly 50\% from 1994 to 1999 (Massa et al., 2004; Consejo Federal Pesquero, 2009).

The aim of this paper was to study the reproductive characteristics of $C$. callorynchus in northern Argentinean coastal waters $\left(36^{\circ} 70^{\prime}-38^{\circ} 10^{\prime} \mathrm{S}\right)$. Particular emphasis was put on estimating the size at first maturation and ovarian fecundity, assessing temporal variations in reproductive activity and determining whether the south-eastern coast of Buenos Aires is a reproductive area for C. callorynchus. This information will be essential to analyze the status of the population of $C$. callorynchus in the south-western Atlantic and implementing conservation and management measures.

\section{Materials and Methods}

Study area and sampling. Specimens of C. callorynchus were obtained monthly from June 2011 to November 2014. They were captured by small-scale artisanal fishermen in Argentinean coastal waters $(<50 \mathrm{~m}$ depths $)$ at three localities from south-eastern Buenos Aires Province: Mar de Ajó (36 $\left.70^{\circ} \mathrm{S} 56^{\circ} 67^{\prime} \mathrm{W}\right)$, Santa Clara del Mar (37 $50^{\circ} \mathrm{S}$ $57^{\circ} 30^{\prime} \mathrm{W}$ ) and Mar del Plata (38 $\left.8^{\circ} 10^{\prime} \mathrm{S} 57^{\circ} 32^{\prime} \mathrm{W}\right)$ (Fig. 1). This is a zone where salinity varies between 32.6 and 34.6 (Martos et al., 2004), and temperature ranges from $8^{\circ} \mathrm{C}$ $10^{\circ} \mathrm{C}$ in winter and $11-14^{\circ} \mathrm{C}$ in spring (Guerrero, Piola, 1997; Lucas et al., 2005).

Individuals were caught using hooks and lines or bottom gillnets and examined immediately after landing or frozen for subsequent analysis in the laboratory. Sex, precaudal length (PCL, in $\mathrm{mm}$ ), total body mass (TM, in $\mathrm{g}$ ), eviscerated body mass (EM, in $\mathrm{g}$ ) and gonad mass (GM, in $\mathrm{g}$ ) were recorded for each individual.

For males, inner clasper length (CL, in $\mathrm{mm}$ ) was measured from the insertion of the pelvic fin to the distal end (Compagno, 1984). For females, maximum oviducal gland width (OGW, in $\mathrm{mm}$ ) and uterus width (UW, in $\mathrm{mm}$ ) were recorded. In the case of mature females, liver mass (LM, in g), oviducal gland mass (OGM, in g), and the number and diameter of the largest vitellogenic ovarian follicles (OFD, in $\mathrm{mm}$ ) were also recorded.

For both sexes, maturity stage was assessed by visual examination of reproductive organs following guidelines by Stehmann (2002), with modifications. Males were assessed as immature when they had testes undeveloped, genital ducts thread-like, frontal tenaculum without denticles and flexible claspers shorter than pelvic fin length. Maturing males had developing testes, genital ducts beginning to coil, frontal tenaculum with small denticles and flexible claspers longer than pelvic fin. Mature males had enlarged and round testes, highly coiled genital ducts, distinct seminal vesicle present (in green colour), frontal tenaculum with numerous sharp denticles and rigid claspers. Females were considered to be immature when they had ovarian follicles undifferentiated, oviducal glands undeveloped and uteri uniformly thin. Maturing females included those individuals with ovarian follicles translucent of different sizes, developing oviducal glands and uteri enlarging caudally. Mature females had vitellogenic ovarian follicles $(>5 \mathrm{~mm}$ diameter with yellow coloration), crescent-shaped enlarged oviducal glands and wide uteri over their entire length.

Data analyses. To study the temporal size variation, length-frequency distributions were compared between periods using the two-sample Kolmogorov-Smirnov test (Crawley, 2005). Samples of C. callorynchus were grouped bimonthly for temporal data analysis due to the small number of individuals present at some sampling times. 


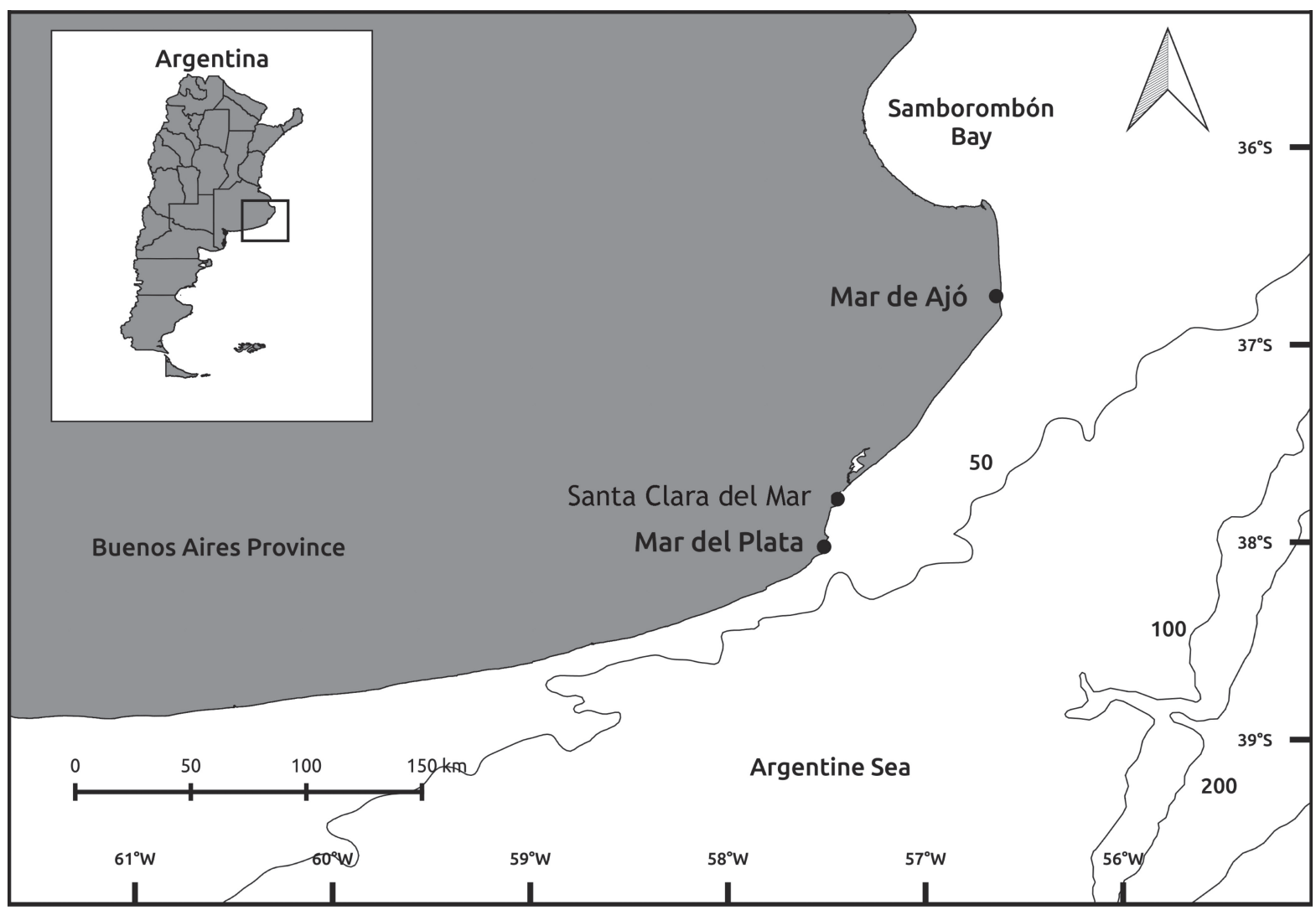

Fig. 1. Map of the study area. Continuous lines are isobaths (in meters). The inset shows the location of the study area in Argentina.

The PCL-TM and PCL-EM relationships were calculated in both sexes by the equation $\mathrm{TM}$ or $\mathrm{EM}=\mathrm{a} \mathrm{PCL}^{\mathrm{b}}$, where $\mathrm{a}$ is the intercept and $\mathrm{b}$ is the slope which were estimated from logarithmically transformed data (Ricker, 1973; Froese, 2006). The value of $b$ provides information on fish growth and it is used to determine whether weight increase is isometric $(b=3)$ or allometric (negative allometry: $b$ $<3$, or positive allometry: $\mathrm{b}>3$ ). The null hypothesis of the isometric growth was tested with the t-test and $95 \%$ confidence limits of the parameter $\mathrm{b}$ were estimated (Zar, 2010; Ogle, 2016).

The onset of maturity was assessed from changes in reproductive organs of males (CL and $\mathrm{GM}$ ) and females (OGW and UW) in relation to PCL. Also, the proportion of mature individuals in $20-\mathrm{mm}$ PCL intervals was calculated. A logistic model was fitted to binomial maturity data (immaturematuring or mature) in order to estimate the length at which $50 \%$ of individuals $\left(\mathrm{PCL}_{50}\right)$ were sexually mature: $\mathrm{P}=1(1+$ $\exp (\alpha+(\beta$ PCL $)))^{-1}$, where $\mathrm{P}$ is the estimated proportion of mature individuals at a given length class, and $\alpha$ and $\beta$ are model parameters (Roa et al., 1999; Crawley, 2007).

Symmetry and functional parity of the ovaries were analyzed. For this purpose, differences in the mean GM, number of ovarian follicles and OFD between right and left ovaries of mature individuals were tested with Wilcoxon paired-sampled test (Zar, 2010). Ovarian fecundity was estimated as the total number of vitellogenic follicles in ovaries and it was plotted against female PCL. Subsequently,
Pearson's correlation was used to evaluate possible changes associated with size increment. Furthermore, the number of atretic follicles in ovaries was recorded, considering flaccid follicles with granulated yolk invaded by narrow blood vessels as atretic (Lucifora et al., 2004).

In addition, gonadosomatic ( $\mathrm{GI}=100 \times \mathrm{GM} / \mathrm{EM})$, hepatosomatic $(\mathrm{HI}=100 \times \mathrm{LM} / \mathrm{EM})$ and oviducalsomatic $(\mathrm{OGI}=100 \times$ OGM/EM) indices (Di Giácomo, Perier, 1994; Capapé, 1999) were calculated for mature females. To assess temporal trends in female reproductive condition, the variations in GI, HI, OGI, OFD and number of vitellogenic ovarian follicles between periods were compared using oneway ANOVA or Kruskal-Wallis test when the assumptions of normality or homogeneity of variances were violated. When significant differences were detected, post hoc comparisons with Tukey's honestly significant difference (HSD) or Dunn's test were performed. All statistical analyses were performed using the R statistical software, version 3.0.1 (R Development Core Team, 2013).

\section{Results}

A total of 186 specimens of C. callorynchus (19 males and 167 females) were captured during June-July (17\%), August-September (22\%) and October-November (61\%) in coastal waters of south-eastern Buenos Aires Province. Specimens of this species were not caught from December to May in the study area. 
The majority of males $(84 \%)$ and females $(74 \%)$ ranged from 420 to $460 \mathrm{~mm}$ PCL and 460 to $560 \mathrm{~mm} \mathrm{PCL}$, respectively (Fig. 2). Results from the Kolmogorov-Smirnov tests indicated no variation in female length-frequency distributions between June-July and August-September $(\mathrm{D}=0.12, \mathrm{n}=70, \mathrm{p}=0.96)$, June-July and October-November $(\mathrm{D}=0.21, \mathrm{n}=128, \mathrm{p}=0.23)$ and August-September and October-November $(\mathrm{D}=0.12$, $\mathrm{n}=136, \mathrm{p}=0.84)$. Females presented the maximum PCL observed (Tab. 1) and they were also heavier than males at sizes $<482 \mathrm{~mm}$ PCL (Fig. 3). Males and females had isometric and allometric growth, respectively (Tab. 1).

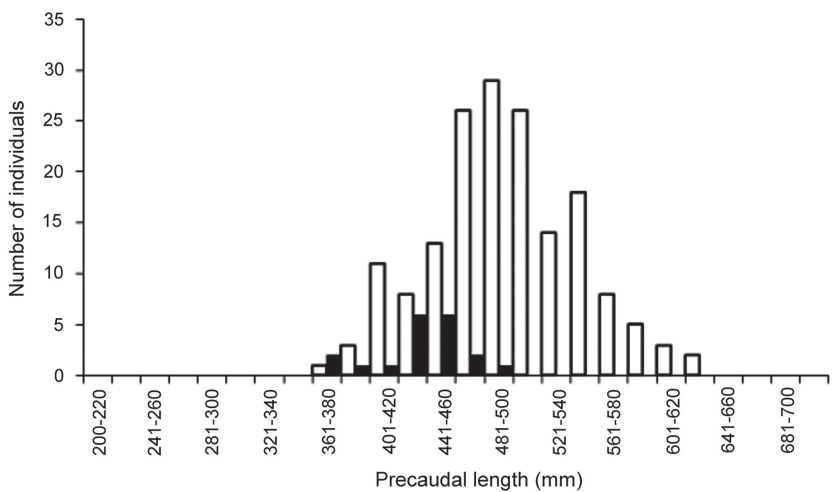

Fig. 2. Length-frequency distribution in 20-mm size classes of Callorhinchus callorynchus males (black columns; $\mathrm{n}=19$ ) and females (white columns; $n=167$ ) sampled.
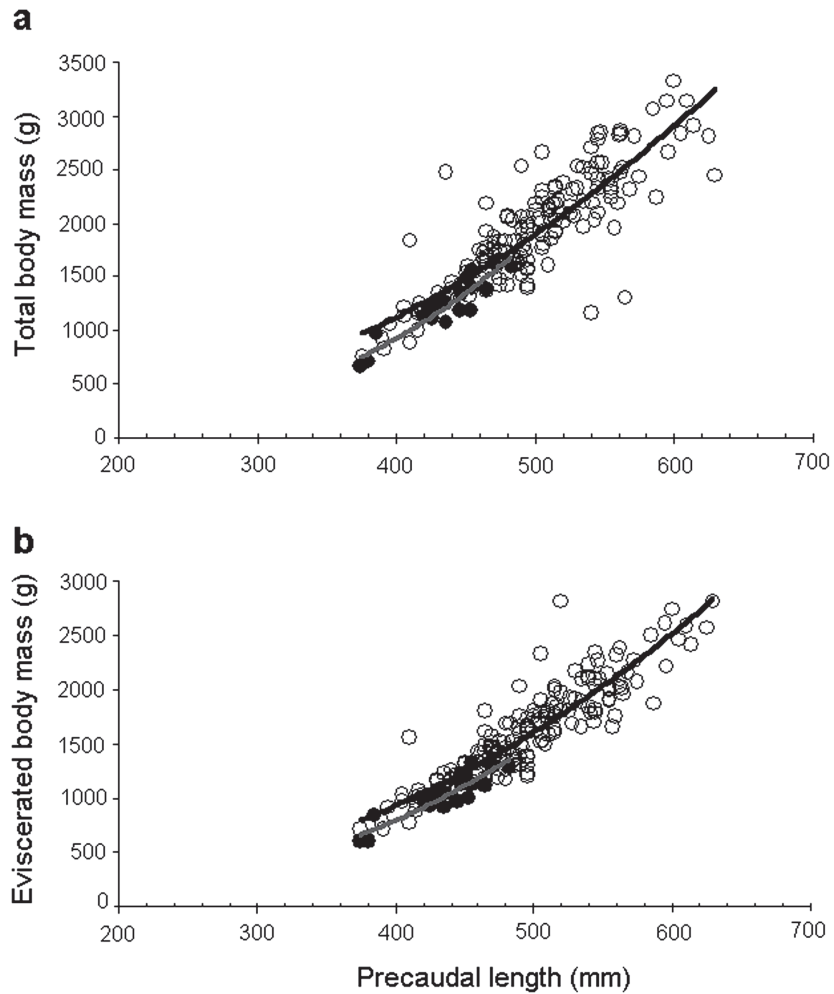

Fig. 3. Relationships for Callorhinchus callorynchus males (black circles; grey line; $\mathrm{n}=19$ ) and females (white circles; black line; $n=167$ ) between precaudal length and a. total body mass and $\mathbf{b}$. eviscerated body mass.
Tab. 1. Morphometric (in $\mathrm{mm}$ ) and gravimetric (in $\mathrm{g}$ ) data, and weight-length relationship parameters for males and females of Callorhinchus callorynchus. n, sample size; PCL, precaudal length (in $\mathrm{mm}$ ); TM, total body mass (in g); EM, eviscerated body mass (in g); s.d., standard deviation; $r^{2}$, determination coefficient; C.I., confidence interval; b, slope.

\begin{tabular}{ccc}
\hline & Males & Females \\
\hline $\mathrm{n}$ & 19 & 167 \\
$\mathrm{PCL}$ & $374-482$ & $375-630$ \\
(mean \pm s.d.) & $(434.47 \pm 29.59)$ & $(498.08 \pm 51.22)$ \\
$\mathrm{TM}$ & $665-1630$ & $755-3330$ \\
(mean \pm s.d.) & $(1226.58 \pm 264.16)$ & $(1928.13 \pm 520.24)$ \\
$\mathrm{EM}$ & $600-1330$ & $710-2820$ \\
(mean \pm s.d.) & $(1021.58 \pm 202.43)$ & $(1635.70 \pm 442.15)$ \\
PCL-TM & $\mathrm{TM}=5 \times 10^{-06 * \mathrm{PCL}^{3.19}}$ & $\mathrm{TM}=9 \times 10^{-03 *} \mathrm{PCL}^{2.34}$ \\
$\mathrm{r}^{2}$ & 0.85 & 0.73 \\
$\mathrm{p}$ & 0.54 (isometry) & $2.31 \times 10^{-0.8}($ negative allometry) \\
95\% C.I. of b & $2.53-3.86$ & $2.12-2.57$ \\
PCL-EM & EM $=1 \times 10^{-04 * \mathrm{PCL}^{2.65}}$ & $\mathrm{EM}=3 \times 10^{-04 *}$ PCL $^{2.49}$ \\
$\mathrm{r}^{2}$ & 0.75 & 0.83 \\
$\mathrm{p}$ & 0.36 (isometry) & $3.03 \times 10^{-08}($ negative allometry) \\
95\% C.I. of b & $1.87-3.43$ & $2.32-2.66$ \\
\hline
\end{tabular}

Males were found in all months in which specimens of C. callorynchus were captured in the study area. The clasper increased remarkably from the $420 \mathrm{~mm}$ PCL onwards, when individuals began to mature (Tab. 2; Fig. 4). The smallest mature male was $420 \mathrm{~mm}$ PCL (16.95 g GM; $77.82 \mathrm{~mm} \mathrm{CL}$ ) and the largest immature male was $425 \mathrm{~mm}$ PCL (1.65 g GM; $43.92 \mathrm{~mm} \mathrm{CL})$. All males $>455 \mathrm{~mm}$ PCL $(>29.17 \mathrm{~g}$ $\mathrm{GM} ;>77.32 \mathrm{~g} \mathrm{CL}$ ) were mature (Tab. 2; Fig. 4). Size at $50 \%$ maturity could not be estimated for C. callorynchus males due to the small sample size.

Tab. 2. Range and sample size for the reproductive variables recorded for male and female of Callorhinchus callorynchus by maturing stage. $\mathrm{n}$, sample size; PCL, precaudal length (in $\mathrm{mm}$ ); GM, gonad mass (in g); CL, inner clasper length (in $\mathrm{mm}$ ); OGW, maximum oviducal gland width (in $\mathrm{mm}$ ); UW, uterus width (in $\mathrm{mm}$ ).

\begin{tabular}{cccccc}
\hline & \multicolumn{5}{c}{ Males } \\
\cline { 2 - 6 } & $\mathrm{n}$ & $\mathrm{PCL}$ & $\mathrm{GM}$ & $\mathrm{CL}$ \\
\hline Inmature & 5 & $374-425$ & $0.84-2.73$ & $15-43.92$ \\
Maturing & 5 & $430-453$ & $12-50.51$ & $67.40-80.32$ \\
Mature & 9 & $420-482$ & $16.95-88.76$ & $74.72-84.52$ \\
\hline & \multicolumn{5}{c}{ Females } \\
\cline { 2 - 6 } & $\mathrm{n}$ & $\mathrm{PCL}$ & $\mathrm{GM}$ & OGW & $\mathrm{UW}$ \\
\hline Inmature & 13 & $375-490$ & $0.41-3.08$ & $8.44-18.24$ & $8.72-19.58$ \\
Maturing & 48 & $391-525$ & $1.60-9.23$ & $11.98-35.80$ & $6.92-25.40$ \\
Mature & 106 & $410-630$ & $4.99-64.77$ & $22.74-55.52$ & $10.90-43.32$ \\
\hline
\end{tabular}



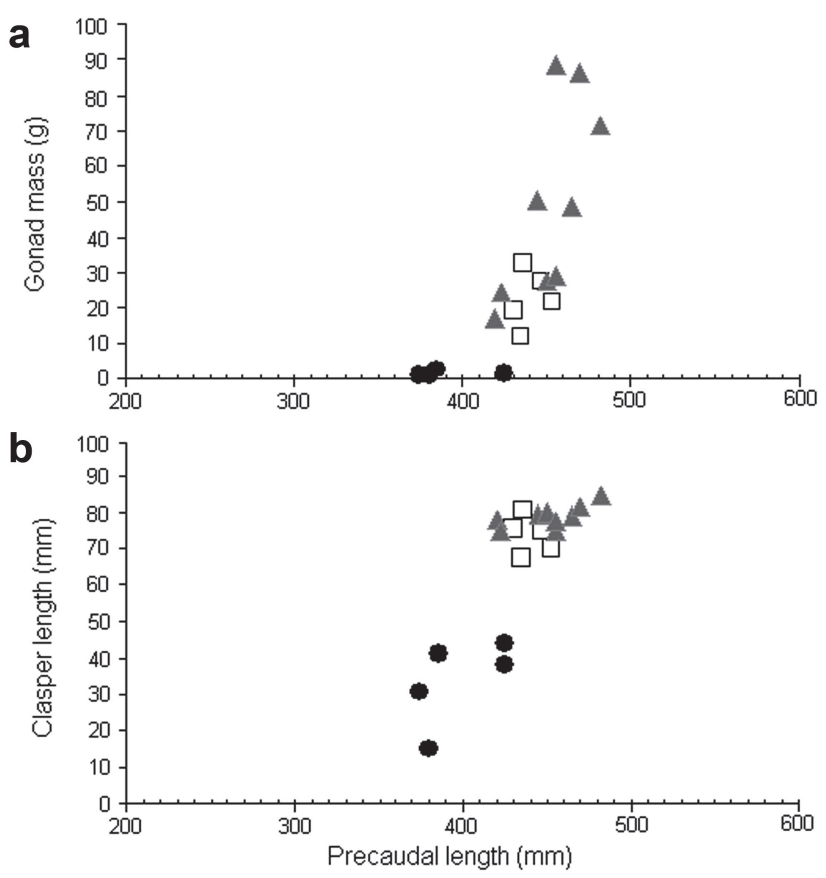

Fig. 4. Relationships between precaudal length and a. gonad mass and b. clasper length of immature (black circles), maturing (white rectangles), and mature (grey triangles) Callorhinchus callorynchus males.

Females were found in every month of capture of $C$. callorynchus. Mature females were predominant in each sampled period. Females with egg cases in their uteri or with spermatophore masses in the seminal receptacle were not found. Females showed a rapid increase in OGW and UW between 420 and $500 \mathrm{~mm}$ PCL (Figs. 5a,b). The smallest mature female measured $410 \mathrm{~mm}$ PCL (25.84 mm OGW; 18.12 $\mathrm{mm}$ UW) and the largest immature $490 \mathrm{~mm}$ PCL (16.68 mm OGW; $13.20 \mathrm{~mm}$ UW). All females $>525 \mathrm{~mm}$ PCL $(>24.62$ mm OGW; $10.90 \mathrm{~mm}$ UW) were mature (Tab. 2; Figs. 5a,b). $\mathrm{PCL}_{50}$ was estimated at $466.22 \mathrm{~mm}$, which corresponded to $74 \%$ PCL of the largest female sampled (Fig. 5c).

Both ovaries were functional. Significant differences between the mass of left and right ovaries were observed (mean \pm s.d.: $8.06 \pm 6.49$ and $6.89 \pm 4.37$, right and left respectively; Wilcoxon paired-sampled test: $V=770, n=67$, $\mathrm{p}=0.02$ ). However, the number of follicles and OFD between ovaries did not differ (Wilcoxon paired-sampled test: $\mathrm{V}=772$, $\mathrm{n}=67, \mathrm{p}=0.66 ; \mathrm{V}=852.50, \mathrm{n}=67, \mathrm{p}=0.11$; respectively). The total number of vitellogenic ovarian follicles ranged from 1 (474 $\mathrm{mm}$ PCL) to 21 (535 $\mathrm{mm}$ PCL) $(8.37 \pm 4.84)$. OFD ranged from $7 \mathrm{~mm}$ (535 $\mathrm{mm}$ PCL) to $43 \mathrm{~mm}$ (470 $\mathrm{mm}$ PCL), with $84 \%$ of them measuring from 10 to $20 \mathrm{~mm}(14.08 \pm$ 6.93). The total number of ovarian follicles was dependent on PCL (Pearson's product-moment correlation: $\mathrm{r}=0.26$, $\mathrm{t}=2.06$, d.f. $=60, \mathrm{p}=0.04$ ) (Fig. 6). Atretic ovarian follicles were observed in females with PCL $\geq 455 \mathrm{~mm}$, but the number of atretic follicles was not significantly related to PCL(Pearson's product-moment correlation: $\mathrm{r}=0.24, \mathrm{t}=1.79$, d.f. $=52, p=0.07)$ (Fig. 6). a

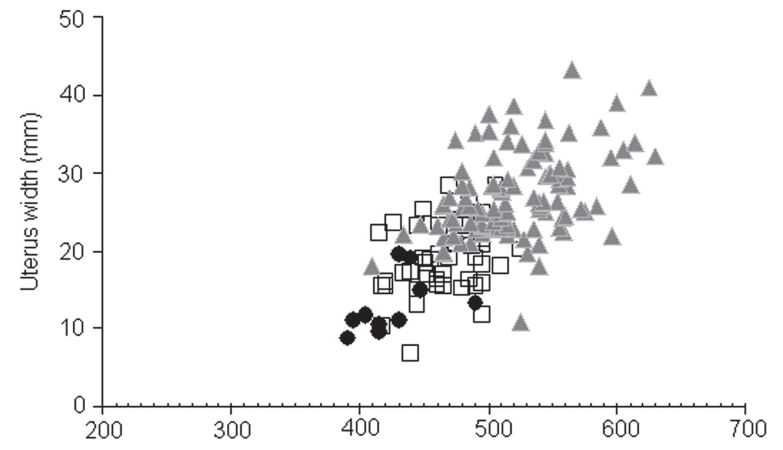

b

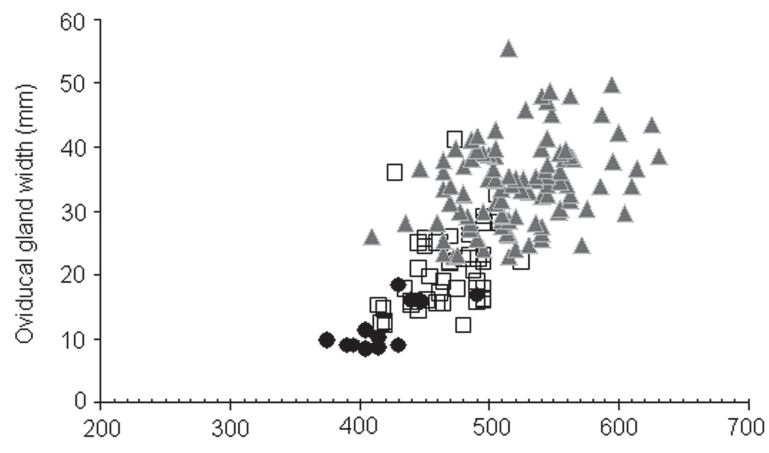

C

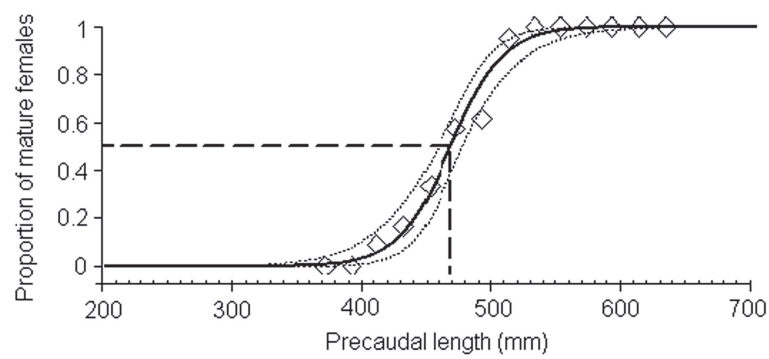

Fig. 5. Relationships between precaudal length and a. uterus width and b. oviducal gland width of immature (black circles), maturing (white rectangles), and mature (grey triangles) Callorhinchus callorynchus females. c. Proportion of mature females in 20-mm precaudal length intervals, showing the logistic ogive fitted (black line) to the observed values (white diamonds) and the $95 \%$ confidence intervals (dotted lines). Long-dashed lines represent the size at 50\% maturity.

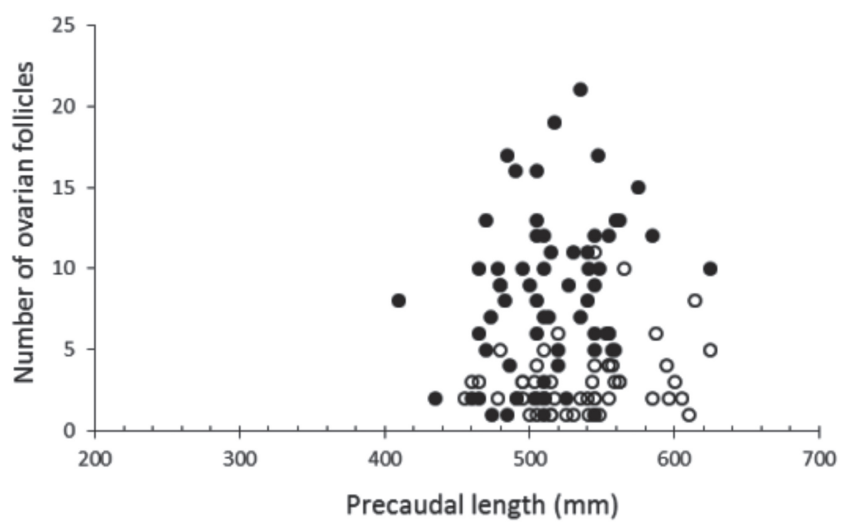

Fig. 6. Relationship between precaudal length and total number of vitellogenic ovarian follicles (black circles) and atretic ovarian follicles (white circles) of Callorhinchus callorynchus females. 
In females, mean $\mathrm{HI}$ was not significantly different among periods (ANOVA: $\mathrm{F}=0.97, \mathrm{n}=98$, d.f. $=2, \mathrm{p}=0.33$ ) (Fig. 7a). However, GI (Kruskal-Wallis: $\mathrm{H}=9.72, \mathrm{n}=100$, $\mathrm{p}=0.01$; Dunn's test: $\mathrm{p}<0.05$ ) (Fig. 7b), OGI (ANOVA: $\mathrm{F}=3.68, \mathrm{n}=84$, d.f. $=2, \mathrm{p}=0.03$; Tukey's HSD: $\mathrm{p}<0.05$ )

a
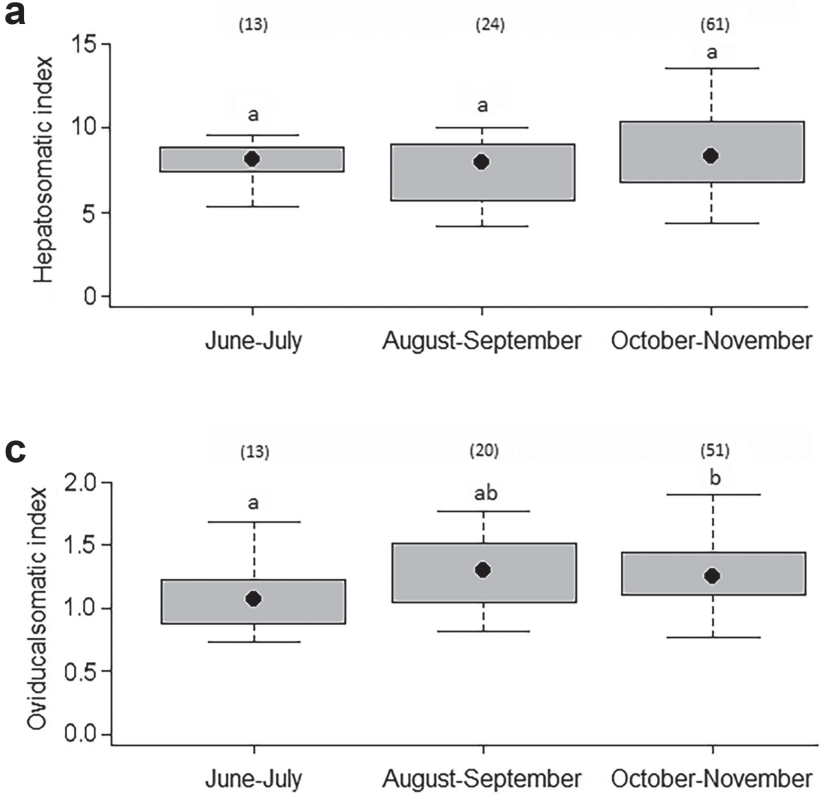

e

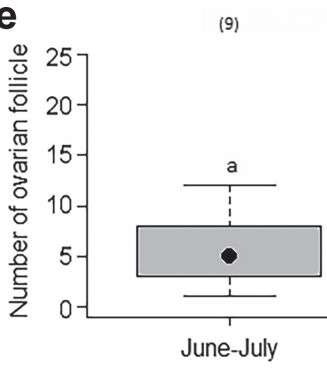

d

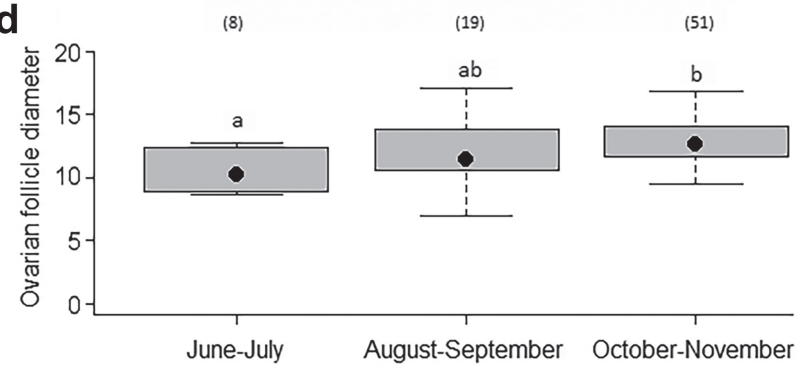

(Fig. 7c) and OFD (Kruskal-Wallis: $\mathrm{H}=7.38, \mathrm{n}=79, \mathrm{p}=0.03$; Dunn's test: $\mathrm{p}<0.05$ ) (Fig. 7d) showed significant seasonal trends, with the highest values in October-November. No difference was found in number of ovarian follicles among periods (Kruskal-Wallis: $\mathrm{H}=5.39, \mathrm{n}=79, \mathrm{p}=0.07$ ) (Fig. 7e).

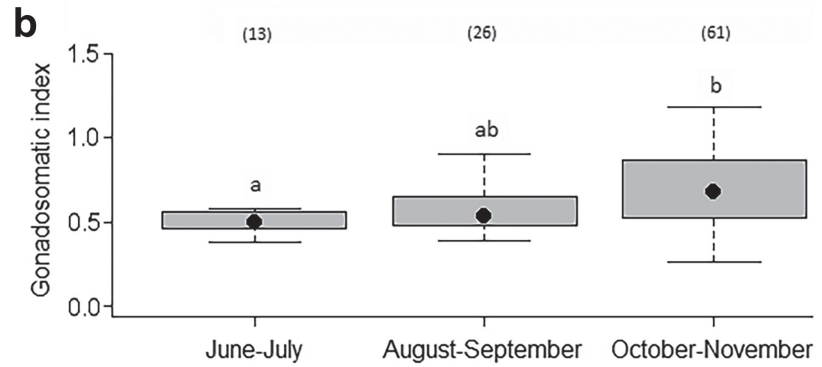

June-July August-September October-November

Fig. 7. Bimonthly variation in a. hepatosomatic index, b. gonadosomatic index, c. oviducalsomatic index, d. diameter of ovarian follicles, and e. number of ovarian follicles in Callorhinchus callorynchus females. The box represents all observed values between the 25 th and 75 th quartiles, and contains the median (black circles) for each category. The box plot whiskers represent the minimum and maximum observations for each category in this study. Numbers in parentheses represent the sample size for each period and distributions with the same letter are not significantly different $(p>0.05)$.

\section{Discussion}

Callorhinchus callorynchus is present in coastal waters of south-eastern Buenos Aires Province (Argentinean Sea between $36^{\circ} 70^{\prime}-38^{\circ} 10^{\prime} \mathrm{S}$ ) from June to November (winterspring). Pellegrino, Cousseau (2005) reported the capture season for this species in the same area from September to March (spring-summer). Physical (temperature, salinity, depth and bottom sediment characteristics) and biotic factors (e.g. reproductive activity) may influence habitat use in chondrichthyans at all spatial scales (Simpfendorfer, Heupel, 2004). Adult migrations and habitat use of $C$. callorynchus in northern Patagonian waters $\left(41-42^{\circ} \mathrm{S}\right)$ were not affected by temperature and salinity (Di Giácomo, 1992).
The distribution pattern of individuals could be determined by prey distribution and availability (Di Giácomo, 1992). The low number of mature males found and the absence of mature females with spermatophore masses or egg cases in coastal waters of south-eastern Buenos Aires Province, suggest that the seasonal presence of this species during winter and spring would not be associated to mating and/or egg laying activity. This distribution pattern could be related to trophic movements as almost all specimens examined had gut contents (Melisa Chierichetti 2015, personal observation). For these reasons, further research is required to analyze habitat use of $C$. callorynchus in the study area in relation to environmental variables and biotic factors, such as food availability. 
Sexual dimorphism in maximum size and body mass was found for $C$. callorynchus in the study area, with females $(\mathrm{PCL}=630 \mathrm{~mm}$; $\mathrm{TM}=3330 \mathrm{~g}$; $\mathrm{EM}=2820 \mathrm{~g}$ ) larger and heavier than males $(\mathrm{PCL}=482 \mathrm{~mm}$; $\mathrm{TM}=1630 \mathrm{~g}$; $\mathrm{EM}=1330 \mathrm{~g}$ ). Sexual size dimorphism is also a common characteristic observed in other holocephalans, with females larger than males (Freer, Griffiths, 1993; Francis, 1997; Nibam, 2011; Bell, 2012). The same pattern was observed for C. callorynchus in northern Patagonian waters (PCL males $=620 \mathrm{~mm}$; PCL females $=760 \mathrm{~mm}$ ) and in Chilean waters $(\mathrm{PCL}$ males $=620 \mathrm{~mm}$; PCL females $=700 \mathrm{~mm})(\mathrm{Di}$ Giácomo, 1992; Alarcón et al., 2011; Bernasconi et al., 2015b). The differences in maximum size among studies for males (present study: $n=19$; northern Patagonian waters: $\mathrm{n}=147$; Chilean waters: $\mathrm{n}=193$ ) and females (present study: $\mathrm{n}=167$; northern Patagonia waters: $\mathrm{n}=1571$; Chilean waters: $n=209$ ) may result from differences in sample sizes. Moreover, the bias in maximum size observed among studies may be explained by sampling depth variations. Samples of specimens in Chilean waters were taken in coastal waters ( $<30 \mathrm{~m}$ depths) as in the present study, but in northern Patagonian waters samples were taken at depths from 20 to $190 \mathrm{~m}$ where individuals of C. callorynchus were segregated by size, with larger individuals at depths $>50 \mathrm{~m}$ (Di Giácomo, 1992; Alarcón et al., 2011; Bernasconi et al., 2015b). For this reason, the frequency size distribution of $C$. callorynchus at depths $>50 \mathrm{~m}$ should be analyzed in waters of south-eastern Buenos Aires Province.

Females of C. callorynchus in this study presented negative allometric growth $(b<3)$, which means that individuals become more elongated with increasing length. However, PCL-TM relationships for both sexes of this species showed negative allometry in northern Patagonian waters and positive allometry $(b>3)$ in Chilean waters ( $\mathrm{Di}$ Giácomo, 1992; Alarcón et al., 2011). These differences result from the fact that within species the variance in weight-length relationships can be substantial, depending on the season, population, and annual or regional differences in environmental conditions (Froese, 2006). Besides, in northern Patagonian waters females were heavier than males at size $>500 \mathrm{~mm}$ PCL, after reaching size at maturity (Di Giácomo, 1992). In contrast, in this study females were heavier than males at size $<482 \mathrm{~mm}$ PCL, before reaching size at maturity.

The $\mathrm{PCL}_{50}$ estimated for females in this study (466.22 $\mathrm{mm} ; \mathrm{n}=167$ ) was similar to that recently obtained in northern Patagonian waters (474.80 mm; $\mathrm{n}=398)$ (Bernasconi et al., 2015b) but smaller than those previously reported in that zone (490 mm; n=123) (Di Giácomo, Perier, 1994) and in Chilean waters ( $500 \mathrm{~mm} ; \mathrm{n}=40$ ) (Alarcón et al., 2011). These differences may be attributable to differences in the methods for assessing maturity and/or in sample size used in each study. Another possible explanation, taking into account that $C$. callorynchus has a widely distribution off southern South America, is that perhaps there are multiple discrete populations of this species with latitudinal variation in size at maturity, as was suggested for several chondrichthyan species around the world (Templeman, 1987; Parsons, 1993; Lucifora et al., 1999; Chiaramonte, Petovello, 2000; Mabragaña, Cousseau, 2004; Colonello et al., 2007; Ebert et al., 2008; Barnett et al., 2009). In turn, the $\mathrm{PCL}_{50}$ estimated in the study area was lower than those values found in northern Patagonian waters, which may be associated with the fact that coastal waters of south-eastern Buenos Aires Province support the highest pressure on chondrichthyans in Argentina (Massa et al., 2004). In the present study, the $\mathrm{PCL}_{50}$ occurred once $C$. callorhynchus female reached $74 \%$ of the maximum observed PCL, maturing at a smaller proportion than C. capensis females in South Africa $(88 \%$ of the maximum size) (Nibam, 2011). The delayed size at maturity in holocephalans, a general pattern in chondrichthyans, indicates that they are particularly sensitive to fishing pressure (Walker, Hislop, 1998; Stevens et al., 2000).

The existence of paired functional ovaries is a common feature among oviparous chondrichthyan species (Hamlett, Koob, 1999). In C. callorynchus both ovaries are functional but differences were found in mass between right and left ovaries of mature females, which was not due to differences either in the number or size of follicles. In mature chondrichthyans, ovaries consist of small follicles, developing follicles of various sizes, preovulatory follicles undergoing atresia, and corpora lutea, which are all embedded together in a dense stroma of connective tissue (Walker, 2005b). The mass difference between right and left ovaries in C. callorynchus may be related to differences in the amount of stromal tissue between ovaries, as it was suggested for other oviparous chondrichthyans, such as the smallnose fanskate Sympterygia bonapartii (Mabragaña et al., 2002).

The mean ovarian fecundity for C. callorynchus off the south-eastern Buenos Aires Province $(8.37 \pm 4.84)$ was higher than that of $C$. capensis off South Africa (mean=5.30 \pm 3.78 ) (Nibam, 2011). The total number of ovarian follicles was dependent on female body size in C. callorynchus, as was observed in other holocephalans (Barnett et al., 2009; Nibam, 2011; Bell, 2012) and oviparous elasmobranchs (Ebert, 2005; Quiroz et al., 2009; Perier et al., 2011; Scenna, Díaz de Astarloa, 2014), which suggest that reproductive potential increases with size. However, it is important to consider that the method of simply enumerating mature follicles to estimate fecundity, under the assumption that all oocytes will be ovulated and become viable egg cases, may be inadequate for oviparous species that reproduce continuously, as enlarged follicles are always present and ovulation may occur at any time (Barnett et al., 2009; Bell, 2012). At the same time, this assumption is not met for $C$. callorynchus because atretic ovarian follicles are commonly observed from the beginning of the female maturation. Atretic follicles form by degeneration of preovulatory follicles and resorption of yolk from the oocytes, atresia can occur at any follicle size (Walker, 2005b). Consequently, the ovarian fecundity of C. callorynchus may be lower than the one estimated in this study. 
Mature females of $C$. callorynchus in the south-eastern Buenos Aires Province were collected mainly in OctoberNovember (spring) coinciding with high values in GI, OGI, and OFD. In northern Patagonian waters, reproductive activity of $C$. callorynchus extends nearly throughout the year, mating and egg laying occur in spring and early summer when females with egg cases in their uteri were found at depths ranging from 20 to $40 \mathrm{~m}$, followed by a short period (one month) of gonadal recovery (Di Giácomo, Perier, 1994). The onset and rate of egg laying is apparently temperature-dependent in oviparous chondrichthyans (Holden, 1975; Boisvert et al., 2015). Optimal temperature for egg productivity in C. milii from Australian waters is $16^{\circ} \mathrm{C}$ and temperatures below $14^{\circ} \mathrm{C}$ would be an environmental trigger to signal the end of the reproductive season, when females would leave the warm coastal waters for deeper waters (Boisvert et al., 2015). Water temperature off the south-eastern Buenos Aires Province during winter and spring are generally $<14^{\circ} \mathrm{C}$ (Guerrero, Piola, 1997; Lucas et al., 2005). Therefore, it may not be an optimal temperature for egg production in C. callorynchus. On the other hand, neonates were not caught and immature individuals were scarce throughout the sampling period, suggesting that the study area is not a nursery ground for $C$. callorynchus. However, further research with additional sampling using other fishing gear would be necessary to asses this latter hypothesis, as juveniles may not be catchable by the used fishing gear. Finally, a high proportion of mature females of C. callorynchus (44\%) caught in the present work had atretic ovarian follicles. Bell (2012) defined resting females of holocephalans as those with corpora lutea or atretic follicles in their ovaries. Probably, most mature C. callorynchus female that seasonally migrate to coastal waters off southeastern Buenos Aires Province are in the resting stage of their reproductive cycle.

The relationship between parental stock and recruitment success must be of prime consideration in the development of an efficient strategy for the exploitation of chondrichthyan stocks (Hoenig, Gruber, 1990). Consequently, it would be essential to carry out sampling of $C$. callorynchus at depths $>50 \mathrm{~m}$ to fully understand the reproductive characteristics of the species in northern Argentinean coastal waters (36 $76^{\circ}$ $\left.038^{\circ} 10^{\prime} \mathrm{S}\right)$. Although the coastal waters off south-eastern Buenos Aires Province would not be a reproductive area for C. callorynchus, a high number of mature females (possibly in the resting stage) arrive seasonally to this zone, where they are subject to fishing mortality. For this reason, this species should be monitored from a fisheries management and species conservation perspective.

\section{Acknowledgments}

We wish to thank artisanal fishermen (Martín, Julio, José and Hector) for sample collection. We are also grateful to David Sabadin for map design, Martina Menegazzi for English grammar suggestions, Santiago Barbini and two anonymous referees for their valuable suggestions that greatly improved the manuscript. Lorena B. Scenna was supported by a fellowship from the Consejo Nacional de Investigaciones Científicas y Técnicas.

\section{References}

Alarcón C, Cubillos LA, Acuña E. Length-based growth, maturity and natural mortality of the cockfish Callorhinchus callorhynchus (Linnaeus, 1758) off Coquimbo, Chile. Environ Biol Fishes. 2011; 92(1):65-78.

Barnett LAK, Earley RL, Ebert DA, Cailliet GM. Maturity, fecundity, and reproductive cycle of the spotted ratfish, Hydrolagus colliei. Mar Biol. 2009; 156(3):301-16.

Bell JD. Reproduction and ageing of Australian holocephalans and white-fin swell shark. [PhD Thesis]. Victoria, AU: Deakin University; 2012.

Bernasconi JF, Perier MR, Di Giácomo EE. Standardized catch rate of cockfish, Callorhinchus callorynchus, in a bottom trawl fishery of Patagonia: Is it possible its use as a predictor of abundance trend? Braz J Oceanogr. 2015a; 63(2):147-60.

Bernasconi JF, Cubillos L, Acuña E, Perier R, Di Giácomo EE. Crecimiento, madurez y mortalidad del pez gallo, Callorhinchus callorynchus, en el Golfo San Matías, Patagonia norte, Argentina. Rev Biol Mar Oceanogr. 2015b; 50(2):283-98.

Boisvert CA, Martins CL, Edmunds AG, Cocks J, Currie P. Capture, transport, and husbandry of elephant sharks (Callorhinchus milii) adults, eggs, and hatchlings for research and display. Zoo Biol. 2015; 34(1):94-98.

Bonfil R. The purpose of stock assessment and the objectives of fisheries management. In: Musick JA, Bonfil R, editors. Elasmobranch Fisheries Management Techniques. Rome: Food and Agriculture Organization of the United Nations; 2005. p.9-20.

Capapé C, Seck AA, Quignard JP. Observation on the reproductive biology of the angular rough shark, Oxynotus centrina (Oxynotidae). Cybium. 1999; 23(3):259-71.

Cedrola P, Bovcon N, Bruno C, Bustamante C, Caille G, Calvo S et al. La pesca deportiva de condrictios en el Mar Argentino. In: Wöhler OC, Cedrola P, Cousseau MB, editors. Contribuciones sobre la biología, pesca y comercialización de tiburones en la Argentina. Aportes para la elaboración del Plan de Acción Nacional. Buenos Aires: Consejo Federal Pesquero; 2011. p.185-192.

Chiaramonte GE, Pettovello AD. The biology of Mustelus schmitti in southern Patagonia, Argentina. J Fish Biol. 2000; 57(4):930-42.

Colonello JH, García ML, Lasta CA. Reproductive biology of Rioraja agassizi from the coastal southwestern Atlantic ecosystem between northern Uruguay $\left(34^{\circ} \mathrm{S}\right)$ and northern Argentina (42 ${ }^{\circ}$ S). Environ Biol Fishes. 2007; 80(2-3):277-84.

Compagno LJV. Species Catalogue for Fishery Purposes. Rome: Food and Agriculture Organization of the United Nations; 1984. Vol. 1, Sharks of the world: An annotated and illustrated catalogue of shark species known to date, pt. 1. Hexanchiformes to Lamniformes. FAO Fisheries Synopsis; 125. 
Consejo Federal Pesquero. Plan de acción nacional para la conservación y el manejo de condrictios (tiburones, rayas y quimeras) en la República Argentina. Buenos Aires: Subsecretaría de Pesca y Acuicultura, Secretaría de Ambiente y Desarrollo Sustentable y Ministerio de Relaciones Exteriores, Comercio Internacional y Culto; 2009.

Cousseau MB, Perrotta RG. Peces marinos de Argentina:biología, distribución, pesca. 4th ed. Mar del Plata: INIDEP; 2013.

Crawley MJ, editor. Statistics: an introduction using R. Chichester: John Wiley and Sons; 2005.

Crawley MJ, editor. The R book. Chichester: John Wiley and Sons; 2007.

Dagit DD, Chiaramonte GE, Romero M, Di Giácomo EE, Acuña E. Callorhinchus callorynchus. In: IUCN Red List of Threatened Species. Version 2012.2 [Internet]. 2007. Available from: http:// www.iucnredlist.org/details/63107/0

Didier DA. Phylogeny and classification of extant Holocephali. In: Carrier JC, Musick JA, Heithaus MR, editors. Biology of sharks and their relatives. Boca Raton: CRC Press; 2004. p.115-135.

Di Giácomo EE. Contribución al estudio biológico-pesquero del pez gallo, Callorhynchus callorhynchus (Linné, 1758), Berg, 1895, en el Golfo San Matías. [PhD Thesis] La Plata (PBA): Universidad Nacional de La Plata; 1990.

Di Giácomo EE. Distribución de la población del pez gallo (Callorhynchus callorhynchus) en el Golfo de San Matías, Argentina. Frente Marítimo. 1992; 12(A):113-18.

Di Giácomo EE, Parma AM, Orensanz JM. Food consumption by the cock fish, Callorhynchus callorhynchus (Holocephali: Callorhynchidae), from Patagonia (Argentina). Env Biol Fish. 1994; 40(2):199-211.

Di Giácomo EE, Perier MR. Reproductive biology of the cockfish Callorhynchus callorhynchus (Holocephali: Callorhynchidae) in Patagonian waters (Argentina). Fish Bull. 1994; 92:531-39.

Di Giácomo EE, Perier MR. Feeding habits of cockfish, Callorhinchus callorhynchus (Holocephali: Callorhynchidae), in Patagonian waters (Argentina). Mar Freshw Res. 1996; 47(6):801-08.

Ebert DA. Reproductive biology of skates, Bathyraja (Ishiyama), along the eastern Bering Sea continental slope. J Fish Biol. 2005; 66(3):618-49.

Ebert DA, Compagno JV, Cowley PD. Aspects of the reproductive biology of skates (Chondrichthyes: Rajiformes: Rajoidei) from southern Africa. ICES J Mar Sci. 2008; 65(1):81-102.

Francis MP. Spatial and temporal variation in the growth rate of elephantfish (Callorhinchus milii). N Z J Mar Freshwater Res. 1997; 31(1):9-23.

Freer DWL, Griffiths CL. The fishery for, and general biology of, the St Joseph Callorhinchus capensis (Dumeril) off the SouthWestern Cape, South Africa. Afr J Mar Sci. 1993; 13(1):63-74.

Froese R. Cube law, condition factor and weight-length relationships: history, meta-analysis and recommendations. J Appl Ichthyol. 2006; 22(4):241-53.

Guerrero RA, Piola AR. Masas de agua en la Plataforma Continental. In: Boschi EE, editor. El Mar Argentino y sus recursos pesqueros. Tomo 1. Antecedentes históricos de las exploraciones en el mar y las características ambientales. Mar del Plata: INIDEP; 1997. p.107-118.
Hamlett WC, Koob TJ. Female reproductive system. In: Hamlett WC, editor. Sharks, Skates, and Rays: the Biology of Elasmobranch Fishes. Baltimore: Johns Hopkins University Press; 1999. p.398-444.

Hoenig JM, Gruber SH. Life-history patterns in the Elasmobranchs: implications for fisheries management. In: Pratt Jr. HL, Gruber SH, Taniuchi T, editors. Elasmobranchs as Living Resources: Advances in the Biology, Ecology, Systematics, and the Status of the Fisheries. Technical Report NMFS. Honolulu: National Oceanic and Atmospheric Administration; 1990.

Holden MJ. The fecundity of Raja clavata in British waters. J Cons Int Explor Mer. 1975; 36(2):110-18.

Lucas AJ, Guerrero RA, Mianzán HW, Acha EM, Lasta CA. Coastal oceanographic regimes of the Northern Argentine Continental Shelf $\left(34-43^{\circ}\right.$ S). Estuar Coast Shelf Sci. 2005; 65:405-20.

Lucifora LO, Menni RC, Escalante AH. Reproductive biology of the school shark, Galeorhinus galeus, off Argentina: support for a single south western Atlantic population with synchronized migratory movements. Environ Biol Fishes. 2004; 71(2):199-209.

Lucifora LO, Valero JL, García VB. Lenght at maturity of the greeneye spurdog shark, Squalus mitsukurii (Elasmobranchii: Squalidae), from the SW Atlantic, with comparisons with other regions. Mar Freshw Res. 1999; 50(7):629-32.

Mabragaña E, Cousseau MB. Reproductive biology of two sympatric skates in the south-west Atlantic: Psammobatis rudis and Psammobatis normani. J Fish Biol. 2004; 65(2):559-73.

Mabragaña E, Lucifora LO, Massa AM. The reproductive ecology and abundance of Sympterygia bonapartii endemic to the southwest Atlantic. J Fish Biol. 2002; 60(4):951-67.

Martos P, Reta R, Guerrero RA. El ambiente físico de las costas marplatenses: su clima y sus aguas. In: Boschi E, Cousseau MB, editors. La vida entre mareas: vegetales y animales de las costas de Mar del Plata, Argentina. Mar del Plata: INIDEP; 2004. p.29-42.

Massa AM, Lucifora LO, Hozbor NM. Condrictios de las regiones costeras bonaerense y uruguaya. In: Sánchez RP, Bezzi SI, editors. El Mar Argentino y sus recursos pesqueros. Tomo 4. Los peces marinos de interés pesquero. Caracterización biológica y evaluación del estado de explotación. Mar del Plata: INIDEP; 2004. p.85-99.

Navarro G, Rozyccki V, Monsalvo M. Estadísticas de la pesca marina en la Argentina. Evolución de los desembarques 20082013. Buenos Aires: Ministerio de Agricultura, Ganadería y Pesca de la Nación; 2014.

Nelson JS, editor. Fishes of the World. 4th ed. Hoboken: John Wiley and Sons Inc; 2006.

Nibam AH. Reproductive biology and diet of the St. Joseph (Callorhinchus capensis) in South Africa. [PhD Thesis]. Cape Town (ZA): University of Cape Town; 2011.

Ogle DH. FSA: Fisheries Stock Analysis. R package. Version 0.8.9. 2016; Available from http://www.fishr.wordpress.com.

Parsons GR. Geographical variation in reproduction between two populations of the bonnethead shark, Sphyrna tiburo. Environ Biol Fishes. 1993; 38(1):25-35. 
Pellegrino JF, Cousseau MB. La pesca deportiva desde la costa en Mar del Plata: los peces costeros. Mar del Plata: Armedenho; 2005.

Perier R, Estalles M, Coller M, Di Giácomo EE. Reproductive biology of the endemic skate Psammobatis lentiginosa in the San Matías Gulf (south-western Atlantic). J Mar Biol Assoc U.K. 2011; 91(6):1165-73.

Quiroz JC, Wiff R, Céspedes R. Reproduction and population aspects of the yellownose skate, Dipturus chilensis (Pisces, Elasmobranchii: Rajidae), from southern Chile. J Appl Ichthyol. 2009; 25(Suppl.1):72-77.

R Development Core Team. R: a language and environment for statistical computing. R Foundation for Statistical Computing; 2013. Available from http://www.r-project.org/

Ricker WE. Linear regression of fishery research. J Fish Res. 1973; 30(3):409-34

Roa R, Ernst B, Tapia F. Estimation of size at sexual maturity: an evaluation of analytical and resampling procedures. Fish Bull. 1999; 97(3):570-80.

Sánchez RP, Navarro G, Rozycki V. Estadísticas de la Pesca Marina en la Argentina. Evolución de los desembarques 1898-2010. Buenos Aires: Ministerio de Agricultura, Ganadería y Pesca de la Nación; 2012.

Scenna LB, Astarloa JMD. Reproductive biology of the Magellan skate, Bathyraja magellanica (Chondrichthyes, Rajidae), in the south-western Atlantic. Mar Freshw Res. 2014; 65(9):766-75.

Simpfendorfer CA, Heupel MR. Assessing habitat use and movement. In: Carrier JC, Musick JA, Heithaus MR, editors. Biology of sharks and their relatives. Boca Raton: CRC Press. 2004. p.553-572.
Stehmann M. Proposal of a maturity stages scale for oviparous and viviparous cartilaginous fishes (Pisces, Chondrichthyes). Arch Fish Mar Res. 2002; 50(1):23-48.

Stevens JD, Bonfil R, Dulvy NK, Walker PA. The effects of fishing on sharks, rays, and chimaeras (Chondrichthyans), and the implications for marine ecosystems. ICES J Mar Sci. 2000; 57(3):476-94.

Templeman W. Differences in sexual maturity and related characteristics between populations of thorny skate (Raja radiata) in the Northwest Atlantic. J Northw Atl Fish Sci. 1987; 7:155-67.

Walker TI. Management measures. In: Musick JA, Bonfil R, editors. Technical manual for the management of elasmobranchs. Fisheries Technical Paper 474. Rome: Food and Agriculture Organization of the United Nations (FAO); 2005a. p.285-321.

Walker TI. Reproduction in Fisheries Science. In: Hamlett WC, editor. Reproductive Biology and Phylogeny of Chondrichthyes. Sharks, Batoids and Chimaeras. USA: Science Publishers, Inc; 2005b. p.81-128.

Walker PA, Hislop JRG. Sensitive skates or resilient rays? Spatial and temporal shifts in rays species composition in the central and north-western North Sea between 1930 and the present day. ICES J Mar Sci. 1998; 55(3):392-402.

Zar JH. Bioestatical analysis. 5th ed. Upper Saddle River (NJ):Prentice Hall; 2010.

Submitted June 22, 2016 Accepted March 17, 2017 by Juan Miguel Mancera 